\title{
Architecture in the Eleventh Century
}

\section{J. H. Parker C.B.}

To cite this article: J. H. Parker C.B. (1873) Architecture in the Eleventh Century, Archaeological Journal, 30:1, 117-126, DOI: 10.1080/00665983.1873.10851591

To link to this article: http://dx.doi.org/10.1080/00665983.1873.10851591

曲 Published online: 11 Jul 2014.

Submit your article to this journal $\widetilde{ }$

Q View related articles ¿ 


\section{ARCHITECTURE IN THE ELEVENTH CENTURY.}

BY J. H. PARKER, C.B.

IN two very interesting old churches that the Institute visited in the course of the year 1872-S. Mary's, Guildford and S. Michael's, Southampton-the same remarliable feature was observed which had previously escaped obserrationthe remains of a small cruciform church enclosed and incorporated in a much larger church of a later period. This sort of economy is very usual in old parish churches, the people preserved as much as they could of the small old church when a larger one was required. The question naturally arose as to what period these two old churches belonged; I considered them as more probably of the first half of the eleventh century than of any earlier period.

In the account that I wrote of S. Mary's, Guildford, for this Journal (see vol. xxix. p. 170), I stated that opinion; and gave as my reason for thinking so, that the generality of the so-called Anglo-Saxon buildings are of the eleventh century, and that there is a wide distinction between those of the first half and those of the second half of that century; during the second half we know that the Norman style came in, but it was not imported as a complete style from Normandy, it was gradually developed after the time of the Conquest, both in England and Normandy (which had then become only one of the provinces of the same lingdom), and the style is properly called by the French antiquaries the Anglo-Norman style. Normandy was a little in advance of England as regards architecture at the time of the Conquest, but not much ; the Anglo-Saxon buildings had greatly improved in construction before the time of the Conquest, and the Norman style had been introduced at Westminster by Edward the Confessor. During the reign of that king we have also the dated example of Deerhurst, A.D. 1053, the construction and decorations of which are very much in advance of the AngloSaxon towers of Lincolnshire and the Dane's land, which be- 
long chiefly to the reign of Cnut, or Canute the Dane. These towers are more common than people are generally aware of; Mr. Matther Bloxam and myself made out and published a list of a hundred of them twenty or thirty years ago, and many more have been observed since that time by Sir Charles Anderson and others. They belong to the churches recorded to have been built by order of Canute on the sites where churches had been burnt by his father or himself during the wars which ended in the settlement of the Danes on the eastern side of England. All this is a very old story, but it seems necessary to recapitulate it, and this brings us clearly to the first half of the eleventh century. My own conviction is that the churches that had been burnt by the Danes were wooden churches, and that the churches built in their places were of "stone and lime," as is recorded in one instance certainly, that of Assandun (Ashington, in Essex). Stone buildings were then becoming more the fashion, there always had been a few, but they were the exception; the general custom was to build of wood as most economical, the country being to a great extent covered with forests.

The question now disputed is, whether these churches were built by persons accustomed to build of cut stone, and were only a continuation of the debased Roman style of building and of construction, or were built by persons accustomed to build of rood only, and are rude and clumsy initations of Roman remains? I take the latter view, and in the paper on the church at Guildford, which I wrote for the Journal, I used the expression "for the long period of five hundred years," as the interval during which the people were accustomed to build of wood only: obviously, I was thinking of England and the north of France only, not of Italy or Aquitaine, but I had omitted to express this, and my very learned friend the Saturday Reviewer ${ }^{1}$ took advantage of the oversight to amuse his readers at my expense, which rather annoyed me when I first heard of it ; but his explanation now has satisfied me, that it is only a renewal of the old battle between us, which has been going on for the last twenty years at intervals, but has never been fairly fought out. That he is a far more learned man than I am I do not for a moment question, and if the matter was one of history only I would not attempt to compete with him.

\footnotetext{
' See the Saturday Review for February 8, 1873, p. 176.
} 
History is a record of things that have been, and depends upon written evidence only. Archæology has to do with existing remains, only compared with, and confirmed by, history. It appears to me that my learned friend and that school have always neglected to pay sufficient attention to the construction of the walls of buildings, and that this is a very material point. It appears to me that the walls of the buildings of the first half of the eleventh century were built by carpenters, and not by masons. Men who were accustomed to build of cut stone would not have built in such a manner.

In all probability the greater part of the buildings recorded to have been built of stone in the tenth century, were built of rough stone or rubble-walling only, and not of cut stone. The ferv buildings that were of cut stone were so very remarkable that they were always recorded and eulogised to a degree that seemed absurd afterwards, but they were so superior to anything the writers had then seen, that they made the most magniloquent description of them. We all know the description in Latin verse of Winchester Cathedral, as built in 980, and yet we also know that a century afterwards it was swept away as not worth preserving; even in the building erected in its place on a new site the construction of the early part is very rude; there is a great waste of material and of labour ; the joints between the stones are extremely wide, and the contrast between this construction and the later work of the twelfth century, after the fall of the central tower, is one of our best guides to the distinction between the construction of the eleventh and of the twelfth centuries. If even quite at the end of the eleventh century the masonry was not further advanced than that, we may well imagine how rude the masonry must have been three generations before that period. Those three generations were a time of rapid progress in the art of building, and this therefore carries us back to the rude construction of those Anglo-Saxon towers, and to the herringbone work in the walls, which is one of the characteristics of that period. All the dated examples of herring-bone work that I know of are of the first half of the eleventh century, and I know of several of that period in various parts of the world. There is one in Rome, dated by an iuscription upon it (the side wall of S. Pudentiana), another 
in Normandy, dated historically, that of the castle of Plessis, and there are others in England also.

I am surprised to see my very learned and able friend trying to revive the old Saxon theory which we thought had been thoroughly upset by Rickman and Willis nearly half a century ago. I published a small work on Ravenna some years since, and I am well acquainted with the buildings of Italy and of France. I therefore could not mean " the long. interval of five hundred years" to apply to any other country than England. It has long been seen and acknowledged that very often the only mode of distinguishing between the construction of the eleventh century and that of the twelfth is by the thickness of the mortar between the joints of the stones. This is well exemplified in the two great abbey churches of Caen as well as in Winchester cathedral. The construction of the first half of the eleventh century is so bad that it is evidently an imitation of the much better construction of an earlier period. The small old church at Bradford, in Wiltshire, is just one that proves my point: the construction is extremely good, such as we do not find anywhere in England or France in the tenth or eleventh century. The joints are as fine as possible, which they never are anywhere in the eleventh century. If the Roman art of building was not lost at least for one generation of men, how does it happen that the art of vaulting (a very important part of Roman architecture) was entirely lost, and no builder ventured to throw a vault over a space of $20 \mathrm{ft}$. wide before the middle of the twelfth century? The general use of wooden buildings in the period between the Roman empire and the twelfth century is the only manner of explaining this. Wide-jointed masonry is always one proof of bad and clumsy construction. The Anglo-Saxon towers of the first half of the eleventh century are evidently the work of carpenters only, of men not accustomed to build of cut stone. No mason would think of placing long pieces of stone vertically up the angles of a tower and make a framework to bind it together. Jarrow and Monks Wearmouth support my view. The monk of Durham ${ }^{2}$ of the time of William I. and II. distinctly says that these churches were in ruins, and overgrown with shrubs, when they were restored by his brother-monks, and

\footnotetext{
2 Symeon Dunelm, Chron. ed. Bedford, p. 201.
} 
ELEPENTH CENTURP ARCHITECTURE.-FEATURES OF CONSTRUCTION.

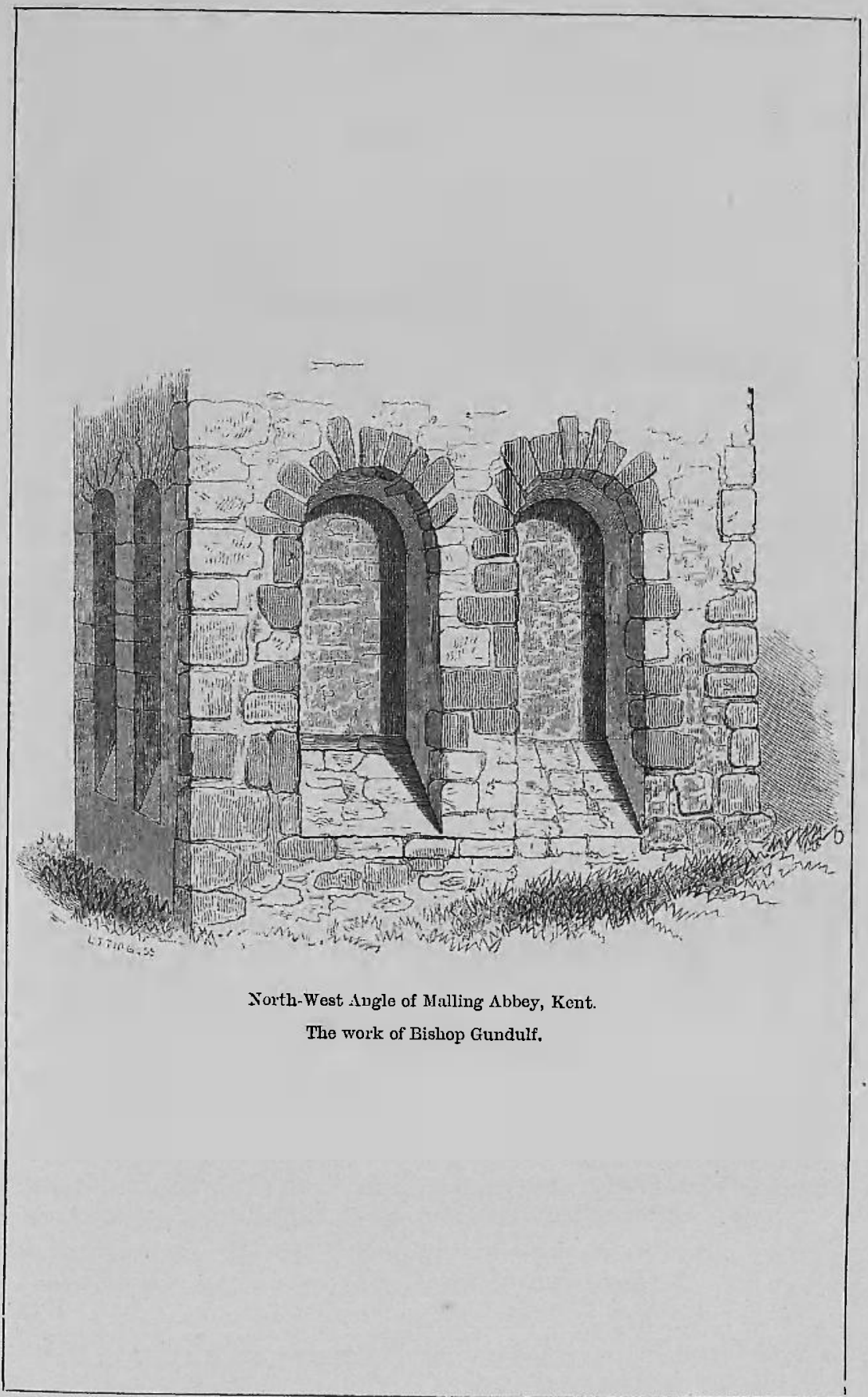


ELEVENTH CENTURY ARGHITECTURS.-TEATURES OF CONSTRUCTION.

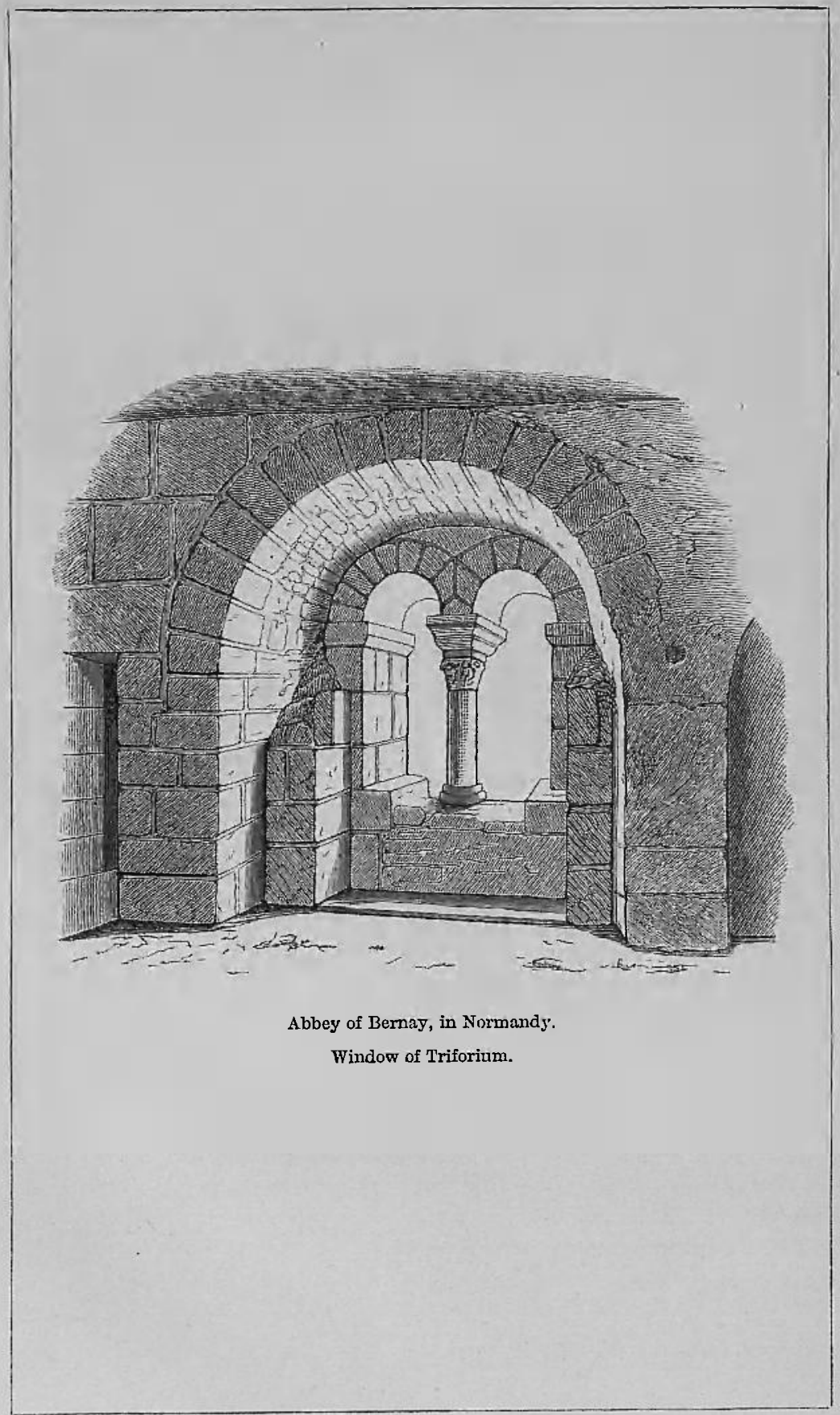


the existing remains agree perfectly with this history. The first time I saw them was in company with the late Mr. Raine, of Durham, who edited the Inventories of those monasteries $^{3}$ for the Surtees Society, and he agreed that the present structures are almost entirely of the later period. I afterwards sent the late $\mathrm{Mr}$. Orlando Jewitt to make drawings of them for me, which he engraved, and which show exactly which parts are of the original period and which are of the end of the eleventh century. Bradford stands in the middle of some of the best stone quarries in England ; it was therefore cheaper to build of stone there in the eighth century. But the greater part of the country was covered with forests, and therefore wood was the natural material to use in most places. This building was exceptional. My much lamented friend, M. de Caumont, of Caen, was certainly one of the best, if not the best, archæologist of France, for the last thirty years. He was the first to introduce the principles, though not the details, of Rickman's system into France, about 1830; and to form an Archæological Society, to make excursions to objects of interest in all parts of France, and compare one province with another. $\mathrm{He}$ and his companions found, by long and frequent observation, that the very distinct provincial character of the different parts of ancient Gaul can all be traced to some one Roman building; which has served as a type for that district, when the revival of building in stone took place. The best known instance of this is the diocese of Lyons, where fluted columns, in evident imitation of their Roman type, are used in the Cathedral in a construction of the thirteenth century, and the same thing occurs in many other churches of that diocese.

For many years past I have been hunting for buildings of the tenth century with very little success. It is matter of history that some stone buildings were erected at that time, but there is very little construction of that period remaining in any of them. I have been a member of the Societé Archæologique de France for the last thirty years, and marle many similar researches with them. M. de Caumont himself went with some friends to the sites of all the castles of the

${ }^{3}$ Inventories and Account Rolls of the Benedictine lonses or cells of Jarrow and Monk Wearmouth in the county of

voL. $\mathrm{xxx}$.
Durham, Publications of the Surtees Society, vol, xxix., 1854. 
Norman barons who came over to England with William the Conqueror, to search for examples of the masonry of that period. To his great surprise and annoyance, he could find no masonry at all in any one of them before the time of the Conquest. He found magnificent earthworks in all of them, but no masonry; showing that the castles of the first half of the eleventh century were of earthwork and wood only in Normandy, where, of all other places, we should have expected them to have been of stone. The Normans were certainly not behind the rest of Europe in the art of building. Even in Italy it is very difficult to find any masonry of the tenth century now remaining. In Rome the only building of that century is the sacristy of the church of Sta. Croce, in Gerusalemme, which is dated by an inscription upon it. The construction of this is as bad as it could be ; a worse construction would not have stood at all. Of the first half of the eleventh century in Rome, the only dated example is the wall of the church of $\mathrm{S}$. Pudentiana, and the construction of that is of herring-bone work. It happens, also, that all the other dated examples of that construction that I know of, are also of the eleventh century, but such simple construction may be of any period. In the celebrated example of S. Remi, at Rheims, the construction of the walls is of the character of the first half of the eleventh century, but all the ornamentation has been added or entirely altered in the twelfth. Some, if not all, of the rich capitals of the twelfth century are made of stucco, fixed upon the plain and rude early stone capitals of the eleventh. When I went there some years since, with M. Viollet-Leduc, who was then in charge of some restorations in that church, we saw one of the stucco capitals that had been broken, and inside of it the early stone capital. About the same time I saw the same thing at Jumieges, in Normandy, with M. B Bouet, the excellent French artist who usually accompanied me in France, and he made a drawing of it, which is here reproduced, and which I put into the fifth edition of the "Glossary of Architecture," in the description of the plates (vol. ii., part i., p. 17), which happened to be then in the press.

In the west front of Lincoln Cathedral the capitals of Bishop Alexander, of the twelfth century, are inserted in the early walls of Remigius. This I detected by the fine jointing 
of the masonry in the insertions, and the wide-jointed masonry of the early work. I had previously sent Mr. Jewitt to make me a drawing of one of the capitals of Remigius, of which there are a few remaining; but he drew me one of Alexander by mistake ; and as he did not draw the jointing of the masonry (for no artist ever thinks of doing so), I did not at first discover the mistake, but saw it at once in a subsequent visit.

The well-known passage from Radulphus (Radolf or Ralph) Glaber, mentioning that "the world seemed to be putting on a new white robe," at the beginning of the eleventh century, which he witnessed, certainly indicates a considerable change at that time, a revival of building in stone, just as another incidental notice in William of Malmesbury, that the buildings of Roger, Bishop of Salisbury, in the beginning of the twelfth century, were so well built that it appeared as if each wall was made of a single stone, indicates that fine-jointed masonry was then first introduced into England as into Normandy. The Norman style is properly called by Viollet-Leduc the "AngloNorman style." It was not introduced as a complete style by the Normans at the Conquest, but was gradually developed in all the provinces of the Anglo-Norman kingdom simultaneously: the variations between England and Normandy amount to no more than provincialisms. The Norman keep of the earliest character that we have either in England or in Normandy is the one built at Malling, in Kent, by Gundulph, in the early part of the reign of William the Conqueror. His invention exactly fitted the wants of the Normans settled in England, and therefore that type was rapidly followed and soon spread all over England and then to Ireland and the Continent. We find Norman keeps everywhere, even in Italy. I am fully convinced, both from my own experience and long observation, and from that of others whom I have known to be careful observers, that buildings of the tenth century are extremely rare, and that on the other hand the first half of the eleventh century was a great building era; and we have many buildings of that period remaining, although that fact has been usually overlooked, and those buildings are commonly supposed to be either much earlier or later. I believe that to be the case with the two rude small and early cruciform churches visited by the Institute in the summer of 1872-St. Mary's, Guildford, and St. Michael's, Southampton-both very wuch of the 
same character, and each enclosed in a much larger church of a later period. The construction is so rude, that it might be of any period when the art of building was in its infancy; but that is exactly what appears to have been the case when the revival of stone building began. It is not debased Roman art, but a rude imitation of it.

Professor Willis, in his admirable history of the Cathedrals of Canterbury and Winchester, does not say that we have any building of the tenth century remaining in either. Archaology has to do with existing remains: "the things that have been" belong to history only. At Winchester the present church was built on a new site, near the old one, not on the same foundations. At York, Professor Willis ridiculed the idea of Browne's history on the very point that Browne supposed the existing building to be the original one. It is possible that there may be some small remains of it in the foundations of the crypt, but it is difficult to make out any, though it is on the old site. At Ripon and at Hexham the old crypts exist, built of fragments of Roman buildings; but their character is quite peculiar, not in the least like the Anglo-Saxon buildings. I have published engravings of them. The church at Bradford, as I have said, is an exceptional case; the fine-jointed masonry proves it not to be of the eleventh century, nor of the tenth; it is most probably of the eighth; although I do not remember one of that period like it anywhere. Still, as a window of the twelfth century seems to be inserted in the old wall, and this wall is certainly not of the tenth or eleventh, I conclude that it must be of the eighth. Shallow sculpture was the fashion then, and the shallow arcade cut in the surface of the old wall may be of that period. I should be very glad if any learned friend would name any other building now existing of that period which corresponds with Bradford. I have spent several months in Aachen, and have drawings and photographs of the church or chapel there, and published a short account of Roman-Moutier and Lorsch with engravings in the "Archæologia." It is well known that very many of the legal documents of the latter half of the tenth century conclude with the words, "the end of the world being at hand:" and this general belief is likely to have had its influence on the buildings of that period, as it appears to me evident that it had. I do not know of three buildings of 
that period remaining in the west of Europe. We all know how the same buildings that are mentioned in grandiloquent terms by the Saxon writers are mentioned with contempt by the Normans a century after (more or less), and were often swept away as not worth preserving. At Soest I was once the means of saving a curious old church from destruction, which may possibly be called of that period; but from its construction I do not believe it to be so. The rules of archæological evidence are our safest guide to the date of a building. "The construction of the same period is always the same." In the only examples of that period that I know of, the construction is as bad as it well could be. This class of buildings is exactly what I mean by those of the first half of the eleventh century, or continuing rather later, perhaps from 1000 to 1080 . The towers of this class in the lower tower of Lincoln we know to have been built after the time of the Norman Conquest. They are rather more advanced in construction than some of the others: they belong to the third generation of masons, after the revival of building in stone. The work of each generation of men may be traced by the construction and the architectural details of their buildings from the time of the kings of Rome, and of the re-building of the Temple of Solomon at Jerusalem, under King Ahaz, to our own days. In the early period all the ornamentation was of wood and bronze; the wood has been burnt, and the bronze melted down, and we have only the rude massive stone walls of the original construction remaining; but these may be divided into three classes ; as I have shown very distinctly in Rome, there is a change in each half century. Such changes are equally distinct in the Middle Ages in England, as is shown by the dates in my "Glossary of Architecture," the first work in which architectural details were ever dated by their historical types.

List of buildings of the Seventh, Tenth, and Eleventh centuries, of which drawings were exhibited in illustration of this Memoir :-

612. Monk Wearmouth.)

680. Jarrow. Rebuilt, 1090.

674. Ripon Crypt; Hexlıam Crypt.

675. Brixworth. 
980. Winchester Cathedral.

Bologna, 7 Churches.

Milan, S. Ambrose.

1000 to 1050 (construction rude herring-bone work).

S. Pudentiana, Rome.

S. Croce, Rome ;-Sacristy.

Plessis, Normandy.

1005-1049. S. Remi, Rheims :-walls.

1014. S. Maurice, Switzerland;-Tower.

1024. Bernay, Normandy.

1041. Stow, Lincolnshire.

1040-1067. Jumieges Abbey, Normandy ;-capitals.

1056. Deerhurst ;-Tower and arch.

1065. Westminster, refectory, \&c.

Castles of Norman Barons.

1070. Malling, St. Leonards, tower; Malling Abbey.

1081. White Tower, London.

In all these buildings the same feature of wide-jointed masonry may be observed, as was shown by drawings of the details.

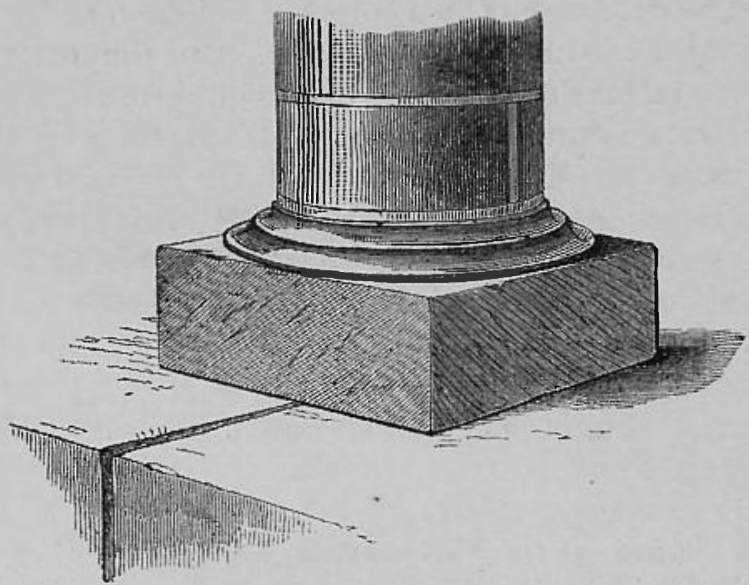

Abbey of St. Etienne, Caen. Base of column in belfry. 